\title{
CORPUS LINGUISTIC-SEMANTIC BASED APPROACH: REVEALING ROHINGYA'S ISSUE THROUGH NOMINALIZATION AS GRAMMATICAL MEANING IN BBC NEWS AND THE JAKARTA POST
}

\author{
Yogi Setia Samsi \\ yogi.setiasamsi@staff.unsika.ac.id \\ University of Singaperbangsa Karawang
}

\begin{abstract}
AntConc is the software that facilitates an unlimited data recognizing the frequency and collocation in order to get categorization of its context. Regarding to Rohingya's issue, it is truly about solidarity and humanity issue in the world. It has been paid attention and concerned by media including BBC News and the Jakarta Post in delivering Rohingya issues. However, media can carry their thought about that issue by numerous ways in delivering their intention. Methodologically, it is qualitatively aimed to identify the tendentious ideology of both media about Rohingya's issue through nominalization as grammatical meaning. As limitation, I employed the analysis as van Leeuwen framework (2008) and semantically (Saeed: 2016) that oriented to reveal both of media's ideology or thought. To comprehend the result, the data is obtained in a week period that inputted to Antconc. The corpus can help and contribute to the analysis especially categorizing a nominalization through frequency and collocation. The findings tend to reveal that both of media have high solidarity toward Rohingya issues. Even though, BBC News is more explicit about raising the actor.
\end{abstract}

Keywords: Corpus, Semantics, Rohingya's issue, Nominalization, BBC News-The Jakarta Post.

\section{INTRODUCTION}

Solidarity is the essential characteristic of unity which has a mutual affection each other. It is a character which had by human life regarding to the expression of their feeling toward happiness and sadness in either other persons or groups. Ironically, some of humans do not have its solidarity that causes many slaughters, wars, and rebellion among nations. In 2017, the world, meant human life, is such devastated to see many victims killed by government contained any politics or other factors. For instance, Myanmar, also called by Birma or Burma, is one of the association of South-East Asian nations (ASEAN) since 1997. It is variously contained by several ethnics either it is original from its country or immigrant from 338 | Jurnal Kredo Vol. 2 No. 2 April 2019 other one whereas most of people who live is muslim or Islam religion such as Rohingya ethnic. Rohingya is the most muslim population in Myanmar. Further, time by the time, the Myanmar's government does have any tolerances, solidarities, and unities. They war the Rohingya people and kill the society both of children and old man of women from Rohingya monitored by the government of Myanmar. Thus, the situation in that country makes many controversial issues among the social media that concerns other nation attention including ASEAN. Moreover, the peak of this problem is Myanmar's government revokes national identity card for Rohingya's people. It affects the Rohingya ethnic gradually leaves and goes to neighbor's country such as Thailand, Malaysia, and Indonesia since 2015. 
Furthermore, all of media from many countries are also really curious about the phenomena happening as a trending topic in the world. They can mediate the reader especially about Rohingnya. It seemed in The Jakarta Post and BBC News because both of media are focused on Rohingya issues. But unfortunately, the polemic in Rohingya issue shows that can affect the various assumptions such as solidarity, humanity, unity, democracy, radical, social-conflict, and others causes due to the text production from media. This is the main problem that produces many assumptions and interpretations from the public. Basicly, a brief news made by media such as newspaper is a written construction of real reality happened in the society and it illustates as a compelling consumption for other societies. the text or discourse is always involves a view of grammatical metaphor either explicitely of implicitely and representational meaning in each media including beyond this country such as $B B C$ News which is officially from America. Therefore, it seemingly interests to analyze how do the media, both of the Jakarta post and BBC News, serve the text regarding to Rohingya issues for the readers from different country.

From the problem aforementioned, it can be identified by corpus linguistic based approach. Corpus linguistic is a branch of linguistic integrating with personal computer since 1990 (baker, 2010:
4). For instance, AntConc software is one of corpus lingusitic tool. It can facilitate unlimited data or text. By using AntConc, the research would be more effective and efficient because it can easily search the word from words, count the frequency of every words, and collocate with before and after its words. Eventhough, AntConc is only able to show the surface data but not for the analysis. In the other words, it is only a mediator that should be supported by other scientific such as semantic analysis (Saeed: 2016) which strenghens CDA specialized the representation as recontextualization by Van Leeuwen (2008). On the other hands, AntConc software is not only used for identifying the dictions semantically but also contributed for representing the implicit meaning of media.

Somehow, there are previous studies have been strongly researching, for instance, about genre analysis through schematic structure made by Flowerdew in Charles et. al. (2009). One of them limits on corpus informed discourse analysis focused on academic engagement by Hyland in Charles et.al (2009). In addition, corpus linguistic is not only related to the core of linguistics, extended linguistics, and hybrid linguistics but also to translation or literature on novel as stated by Malhberg, et.al (2013). They said that corpus also can be applicable to novels. Regarding to this case about nominalization, it was discussed by Hou (2014) found that corpus 
linguistics is used to identify nominalization in translation of Chinese literary prose. Further, Atai \& Hossein (2017) made a similar analysis that focused on the representation of editorial newspaper in some cases. Furthermore, there was very relevant study with this current one researched by Susinskiene (2010). It was about the nominalization in British newspaper.

The aforementioned researches are still too general about analyzing the nominalization related to the translation by Hou (2014) and its corpus based (Charles: 2009) and (Malhberg, et.al.: 2013) even though, Atai \& Hossein (2017) studied closer to this present research due to about representation of media of newspaper. However, the most relevant research that inspiringly adopted is discussed by Susinskeine (2010). It caused by the focus of the study was about nominalization as cohesion device in newspapers. The finding was not about social issues like solidarity, humanity, or others. Therefore, here is coming as the gap among previous research to complete or enrich the research focusing on nominalization in newspapers with raising a solidarity issues.

Thus, this present research will reveal enthusiastically editorial newspaper in delivering the rohingya's issues more specific analysis involved corpus linguistics interfaces with critical discourse analysis, morphology and semantics studies. It is also called by an essential gap and an advantage of this research that highlights the solidarity issues which is still rare to be researched. Therefore, this current study is emphasized on how do media represent their thought in producing their text grounded by van Leeuwen (2008); Atai\& Hossein (2017), nominalization Susinskiene (2010); (Hou: 2014), and grammatical meaning (Saeed: 2016) through AntConc software in the Jakarta Post and BBC News. Considering the gap and focus of this study can make public aware and realize about solidarity issue especially in Rohingya's conflict.

\section{Corpus Linguistics and Antconc Software}

McEnery and Wilson (1996: 1) in Baker's book (2010) argued that corpus linguistics is a relatively recent branch of linguistics, made popular since the advent of personal computers in the 1990s. They added that it is the study of language based on examples of real life language use. As etymology, the word corpus comes from the Latin word for body; its plural is corpora. A corpus is therefore a 'body' of language, or more specifically, a (usually) very large collection of naturally occurring language, stored as computer files. One of corpus linguistic tools is named by AntConc software. AntConcs are an important aspect of corpus linguistics in that they allow qualitative analysis to be carried out on corpus data, letting the researcher explore individual cases 
in detail. Sorting AntConc data alphabetically is an often-used way to identify patterns quickly and also on a different word position is likely to produce different patterns. Simply, AntConcs also allow the researchers to identify linguistic patterns, which can be based on grammar, form, meaning, pragmatics, and discourse. Briefly, I outline some techniques or corpus processes that can be carried out on corpus data as Baker (2010). First, frequency, it is additionally used to examine frequencies of multi-word units (also known as clusters, chunks, multi-word sequences, lexical phrases, formulas, routines, fixed expressions, and prefabricated patterns). Second, collocation is a way of demonstrating (relatively) exclusive of frequent relationships between words (or other linguistic phenomena). If two words collocate, then they have a tendency to occur near or next to each other in naturally occurring language use. Therefore, it can indicate a relationship, but we may need to carry out concordancing work in order to identify exactly how the relationship is manifested in language. They are several ways of calculating collocation, each which emphasizes different types of relationships in terms of frequency and exclusivity. The simplest way is to count the number of times that word $x$ occurs near word $y$ manually.

Third, keywords are a way of taking into account relative frequencies between corpora, which is a useful way of highlighting lexical saliency. For example, the word the is generally very frequent in most corpora, so knowing that it is frequent in a corpus that we are examining may not be particularly exciting - is simply tell us that our corpus is typical of most language use. Fourth, a AntConc is a table of all the occurrences of a linguistic item in a corpus, presented within their linguistic context (usually a few words to a few lines either side of the linguistic item).

From the theories aforementioned, Tognini-Bonelli (2001: 1) in Baker's book (2010) concluded that they do agree with McEnery's statement but they note the distinction from its statement. The note is we cannot view corpus linguistics as an 'independent branch of linguistics in the same way as phonetics, morphology, syntax, semantics, or pragmatics. On the other hands, corpus linguistics should be supported by other branch of linguistics in identifying any cases.

\section{Representation as Recontextualization}

In this part, it briefly explicates about a part of social event. To represent social event, one is incorporating it within the context of another social event, or called by recontextualizing it. Van Leeuwen (2008) divides into two classifications namely exclusion and inclusion. Moreover, it is coming to explicate exclusion elements. They 
are consisted of first, passive, it is indicated by material processes and its participants (subject or choice leaves) that indicated by nominalization. Furthermore, the other classification is inclusion elements that contained by presence, abstraction, arrangement, addition, deletion, and substitution. But unfortunately, especially this inclusion elements are not involved in this research.

Furthermore, to investigate the representation of meaning, it should start from the analysis of its nominalization as Hou's (2014) framework. It is about the kinds of nominalization such nominalization as adverbial, nominalization in subject position, and nominalization in object position. Explicitly, to find out the nominalization as adverbial, it is potentially found by starting the word of preposition such as by, in, with, on, etc. Otherwise, to obtain the nominalization in subject position and object position are usually signaled by suffix -ing, or started by any articles such as the, $a$, and an. Nevertheless, both of nominalization can be differed by the position and context. After analyzing those nominalizations, it could be formulated the frequency of occurring in the text regarding to nominalization.

To deepen and strengthen the findings, the framework of Van Leeuwen (2008) and Hou (2014) will be interfaced with the framework of Saeed (2016: 53). It is concerned with the analysis of grammatical

342 | Jurnal Kredo Vol. 2 No. 2 April 2019 meaning. He claimed that words can be identified at the level of writing, where are familiar with them being separated by white space, where it is called by orthographic words. It also can be identified both of phonology, where they are strings of sounds that may show internal structuring which does not occur outside the word, and syntax, where the same semantic word can be represented by several grammatically distinct variants. Grammatical meaning can be found when the lexical meaning integrated by other morphemes such as affixations, -ing, or indicating as passive verb. By attaching with other morphemes, both of form and meaning are totally changing. Thus, it is called by grammatical meaning.

\section{METHODOLOGY}

In this section, the research uses qualitative approach and descriptive method. Moreover, qualitative approach is able to draw, analyze, and criticize every individuals in their life. The data is written text and it is obtained by two newspapers namely the Jakarta Post and BBC News. The total of texts randomly collected from their website are 20 articles that consist of 10 articles from the Jakarta post and 10 others from $B B C$ News in a week as period. Those articles are inserted into AntConc software. The representation of both media will be identified, through corpus linguistic based on AntConc software, by first, Hou (2014) about nominalization 
framework, second, Saeed (2016) framework as analyzing grammatical meaning, third, Van Leeuwen (2008) framework in representing the meaning Furthermore, to strengthen the result, the researcher takes sample randomly about 5 participants in order to obtain the reader's responses.

\section{ANALYZING NOMINALIZATION CATEGORIES}

From the text about Rohingya news which is obtained by $B B C$ News and The Jakarta Post, the researcher attempts to analyze the nominalization either as subject, object, or adverbial functions. In the text of $B B C$ News, it contains of 4256 words, otherwise, the text of the Jakarta Post gets 7441 words which is collected in a week. From the article collections, they are processed based on corpus linguistic approach through AntConc application. Further, the technique of analysis related to (Hou: 2014) in his journal and integrated with grammatical meaning (Saeed: 2016). Moreover, the researcher explains the result of findings from nominalization, first, Data of BBC News, and second, Data of the Jakarta Post. Data of $B B C$ News

\subsubsection{Analysis of the nominalization as adverbial category}

Table 1. Distribution of frequency and collocation occurring nominalization as adverbial

\begin{tabular}{|c|c|c|}
\hline Word & $\begin{array}{l}\text { Frequency/ } \\
\%\end{array}$ & Sentence/ Collacation \\
\hline Government & $13 / 0.287 \%$ & ... a charge vehemently denied by the government $\underline{o f}$. \\
\hline Fleeing & $4 / 0.088 \%$ & ... arrivals are traumatized $\underline{\text { after }}$ fleeing $\underline{\text { killings } . . .}$ \\
\hline Burning & $3 / 0.066 \%$ & $\begin{array}{l}\text {... are traumatized after fleeing killings } \underline{\text { and }} \text { burning } \\
\underline{\text { villages }}\end{array}$ \\
\hline Investigation & $2 / 0.044 \%$ & In the $\underline{B B C}$ investigation, $\underline{\text { sources }}$ in the... \\
\hline Developments & $1 / 0.022 \%$ & ...many are feeling nervous $\underline{\text { about }}$ developments $\underline{\text { in }} .$. \\
\hline Firing & $1 / 0.022 \%$ & ...by police officers firing automatic weapons. \\
\hline
\end{tabular}

In this analysis, the word 'government, fleeing, burning, investigation, developments, and firing' in the article of $B B C$ News is one of nominalization category aiming as adverbial or complement in a sentence. The word comes from the verb which is to be noun by suffix '-ment, -ing, and-ion' to the stem of 'govern, flee, burn, investigate, develop, and fire'. Moreover, the frequency of words above in $B B C$ News within the texts of Rohingya is various and has a range to $13 \%$. To make clearer, the data can be seen in the table above.

In addition, the most frequency of collocation from the left side of the word 'government' is 'the' and from the right side is ' $o f$ '. In 
accordance with collocation, the word 'fleeing' collocates with 'after' in the left side and the right one with the noun 'killings'. The word 'burning' collocates with 'and', otherwise in other side, it collocates with other noun 'villages', and others can be analyzed in the table above. Semantically, according to Saeed (2016) about grammatical meaning of prefix -ment in the word 'government and development', potentially mean as 'a group that has a right and a process gradually'. Moreover, grammatical meaning of ing in the word 'fleeing, burning, and firing', as adverbial, mean 'an activity which is happening in time or usually collocates with preposition'. In other case, grammatical meaning of -ion in 'investigation' within this contexts is 'a strong effort that should make it true'.

\subsubsection{Analysis of the nominalization in the subject position category}

Table 2. Distribution of frequency and collocation occurring nominalization as subject

\begin{tabular}{|c|c|c|}
\hline Word & $\begin{array}{l}\text { Frequency/ } \\
\%\end{array}$ & Sentence/ Collocation \\
\hline Donation & $4 / 0.088 \%$ & ... The donation has been made to... \\
\hline Movement & $4 / 0.088 \%$ & ...what the movement will do next... \\
\hline Decision & $2 / 0.044 \%$ & ...the decision was linked to her failure... \\
\hline $\begin{array}{l}\text { Discriminat } \\
\text { ion }\end{array}$ & $1 / 0.022 \%$ & $\begin{array}{l}\text {...the discrimination mainly emanates from the } \\
\text { government }\end{array}$ \\
\hline Prevention & $1 / 0.022 \%$ & Prevention $\underline{i s}$ essential \\
\hline
\end{tabular}

In this category, the word 'donation, movement, decision, discrimination, and prevention' are one of nominalization in the subject position category in the sentence. Those words come from the verb with attaching suffix '-ment and ion' through the stem 'donate, move, discriminate, and prevent'. In addition, frequency regarding to the words aforementioned are variety such as the word of donation and movement have 4 times frequencies or $0,008 \%$, the word of decision has 2 times or $0,044 \%$, and so on.

344 | Jurnal Kredo Vol. 2 No. 2 April 2019
Furthermore, the collocation potentially appears in the left side of 'donation' is 'the' and the right side is 'has'. Moreover, the word 'movement' collocates with 'the' in the left side and the right one with helping verb and modal one such as 'will'. The word 'decision' collocates with 'the', otherwise in right one can be with 'to be' for instance 'was', and others can be seen in the table above. As semantically, grammatical meaning of -ion in the words 'donation, decision, discrimination, and prevention', one of them can be meant as 'a thing or choice which 
given and an action for doing stem 'movement' within this context something'. In the other cases, means 'to show an action'. grammatical meaning of -ment in the

\subsubsection{Analysis of the nominalization in the object position category}

Table 3. Distribution of frequency and collocation occurring nominalization as object

\begin{tabular}{|c|c|c|}
\hline Word & Frequency/ \% & Sentence/ Collocation \\
\hline Killings & $4 / 0.088 \%$ & ...reports of rape and extra-judicial killings. \\
\hline Immigration & $1 / 0.022 \%$ & 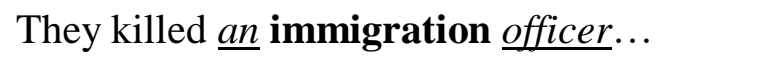 \\
\hline $\begin{array}{l}\text { Mistreatmen } \\
\mathrm{t}\end{array}$ & $1 / 0.022 \%$ & $\begin{array}{l}\text {...time to fight against the mistreatment of } \\
\text { Rohingya }\end{array}$ \\
\hline
\end{tabular}

In this part, the word 'Killings, Immigration, and Mistreatment' comes from the verb which is to be noun by adding suffix '-ing, -ion, and -ment' in the stem 'kill, immigrate, and mistreat' as an object of subject activity process. Further, the frequency related to the words above relatively occurs 1 until 4 times with percentage $0,088 \%$.

In addition, the collocation which is potentially appears in the left side of 'killings' is adjective such as 'extra-judicial'. Moreover, the word 'Immigration' collocates in the left side with an article ' $a n$ ' and other side is the word 'officer'. The last one, the word 'mistreatment' collocates with 'the', otherwise, in the right side is with preposition ' $o f$ '. As Saeed (2016) defined semantically that grammatical meaning of -ion,-ing, and -ment have already discussed in previous category above.

\subsection{Data of The Jakarta Post}

\subsubsection{Analysis of the nominalization as adverbial category}

Table 4. Distribution of frequency and collocation occurring nominalization as adverbial

\begin{tabular}{|c|c|c|}
\hline Word & $\begin{array}{l}\text { Frequency/ } \\
\%\end{array}$ & Sentence/ Collocation \\
\hline Fleeing & $10 / 0.134 \%$ & ...new arrivals are traumatized $\underline{\text { after }}$ fleeing $\underline{\text { killings... }}$ \\
\hline Revealed & $5 / 0.067 \%$ & UN failures on Rohingya revealed. \\
\hline Movement & $3 / 0.040 \%$ & ...using $\underline{\text { insurgent }}$ movements $\underline{\text { to }}$ exert cross-border... \\
\hline Salvation & $3 / 0.040 \%$ & 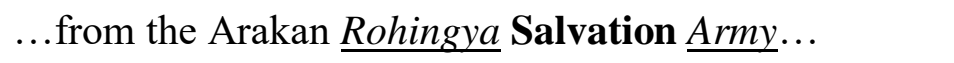 \\
\hline Sanitation & $3 / 0.040 \%$ & ...there is no access to water $\underline{\text { and }}$ sanitation facilities... \\
\hline Suffering & $3 / 0.040 \%$ & 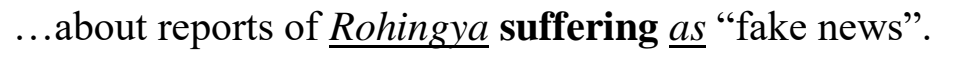 \\
\hline Attacking & $2 / 0.027 \%$ & ...of indiscriminately attacking Muslims and burning... \\
\hline Shooting & $2 / 0.027 \%$ & ...including shooting fleeing civilians... \\
\hline
\end{tabular}


In this part, we are coming to other data. It is from the Jakarta Post newspaper which is directly discussed below. The word 'fleeing, revealed, movement, salvation, sanitation, suffering, attacking, and shooting' within the article of The Jakarta Post is one of the nominalization as adverbial categories. Those words come from the verb which is to be a noun by adding suffix '-ment, -ing, -ed, and ion' in the stem 'flee, reveal, movement, salvation, sanitation, suffering, attacking, and firing'. Furthermore, the frequency of aforementioned words in the articles of the Jakarta Post are too various and the most frequency is the word fleeing about 10 times or $0.134 \%$.

Moreover, the collocation which always appears in the left side of 'fleeing' is preposition 'after' and other side is a noun 'killings'. The word 'revealed' collocates with a noun 'rohingya', and other cases can be seen in the table above. Semantically, grammatical meaning of -ing in the stem 'fleeing, suffering, attacking, and firing', as adverbial, mean 'as same as a process which is happening'.

\subsubsection{Analysis of the nominalization in the subject position category}

Table 5. Distribution of frequency and collocation occurring nominalization as subject

\begin{tabular}{|c|c|c|}
\hline Word & $\begin{array}{l}\text { Frequency/ } \\
\%\end{array}$ & Sentence/ Collocation \\
\hline Movement & $7 / 0.094 \%$ & .. last two $\underline{\text { days }}$, movement $\underline{\text { across }}$ the border... \\
\hline $\begin{array}{l}\text { Discriminatio } \\
\mathrm{n}\end{array}$ & $2 / 0.027 \%$ & $\begin{array}{l}\text {...He argues that the discrimination mainly } \\
\text { emanates... }\end{array}$ \\
\hline Operation & $4 / 0.054 \%$ & $\underline{T h e}$ operation $\underline{i s}$ clearly... \\
\hline Launched & $4 / 0.054 \%$ & launched simultaneous attacks on Myanmar... \\
\hline Decision & $3 / 0.040 \%$ & ...then the decision $\underline{\text { had }}$ nothing to do... \\
\hline
\end{tabular}

The result of analysis from the words "movement, discrimination, operation, launched, and decision" above, those words have a category of nominalization which places as subject. This case actually should be occurred in all of texts to hidden the subject or the actor. Ironically, it is only $7 \%$ that indicates as the most occurrence such as "movement" in the Rohingya issues. It means that the writer does not focus on developing the goal or purpose through the words.

The collocation which is most occurrence in the left side of 'movement' is the adverb of time such as 'days' otherwise in the right side is the word 'across'. Moreover, in the left side that collocates with the word 'discrimination' is article 'the' and 'mainly' is adapted with the verb such as 'emanates', and so on. In addition, as semantically, the word 'movement', has already clear 
explanation, it has an effort to show an action. Further, the frequency which appears in every words above has a range between 2 until 7 times or $0.027 \%-0.094 \%$.

\subsubsection{Analysis of the nominalization in the object position category}

Table 6. Distribution of frequency and collocation occurring nominalization as object

\begin{tabular}{|c|c|c|}
\hline Word & $\begin{array}{l}\text { Frequency/ } \\
\%\end{array}$ & Sentence/ Collocation \\
\hline Killing & $2 / 0.027 \%$ & and killing many of its inhabitants. \\
\hline Situation & $7 / 0.094 \%$ & ..I watch the news and see the situation $\underline{i n}$ Burma. \\
\hline Seeing & $6 / 0.081 \%$ & he described hearing shooting, and seeing $\underline{\text { burning... }}$ \\
\hline Burning & $6 / 0.081 \%$ & Officials have accused Arsa militants of burning the. \\
\hline $\begin{array}{l}\text { Constructin } \\
\mathrm{g}\end{array}$ & $2 / 0.027 \%$ & $\begin{array}{l}\text {...savings on transportation and constructing } \underline{a} \\
\text { shelter... }\end{array}$ \\
\hline Stateless & $4 / 0.054 \%$ & ..minority group $\underline{\text { rendered }}$ stateless $\underline{i n} . .$. \\
\hline
\end{tabular}

As morphologically, the word "killing, situation, seeing, burning, constructing, and stateless" in the article of Rohingya is formed by the verb 'kill, situate, see, burn, construct, and state' added by -ing, ion, and -less, then it is to be nominalization. In other case, those nominalizations place as an object because they are preceded by the subject and predicator. Furthermore, the frequency in every words are relatively around of 5 until $7 \%$.

From the result of corpus linguistic analysis above, it can be summarized that the collocation which always appears in the left side of 'killing' is the preposition 'and', otherwise, in the other side always occurs the word 'many'. On the other hands, the grammatical meaning of suffix -ing in the stem 'killing' means as an activity which is happening. Moreover, the nominalization of word 'killing has a position as an object which has a frequency around $2 \%$.

\section{Formulating Nominalization Categories}

From the analysis result of BBC News and the Jakarta Post above, the researcher concludes that all of nominalization can express the issue in a discourse both of written and spoken. By using corpus linguistic tool, the identifying will be easier than using a conventional ways. However, the keyword, frequency, collocation, AntConc, and context can be known and analyzed in the corpus tool depending on the need (Baker: 2010). From the result of corpus tool production, it helps the researcher to close the conclusion although the corpus tool is only available to tend not to conclude the discourse. Here also, the researcher 
potentially formulates the schema to form the three kinds of nominalization that combined with grammatical processes.

1. Formulation of nominalization as adverbial

In this part, the formulation is formed as adverbial position. From the analysis result above, it can be formulated that nominalization as adverbial has 11 rules based on the article of 'BBC News' and 'the Jakarta Post'. They are; the + NOM; after + NOM; and + NOM; in the $B B C+N O M ;$ about + NOM; by police officers + NOM; rohingya + $\mathrm{NOM}$; insurgent + NOM; of + $N O M$; indiscriminately $+N O M$; and including + NOM.

2. Formulation of nominalization in subject position

In this second part, the formulation is shaped by nominalization as actor in subject position. From the analysis result in finding, it can be summarized that the researcher formulates 2 rules of nominalization as subject position based on the article of 'BBC News' and 'The Jakarta Post' for instance; the + NOM; and last two days + NOM.

3. Formulation of nominalization in object position

The third part is the formulation that formed by nominalization as object position. From the finding aforementioned, the researcher formulates 6 rules of nominalization as object position regarding to the article of both newspapers. Here is the formulation, namely 'and exrajudicalt + NOM; an + NOM; the + NOM; and + NOM; of + NOM; and renderd + NOM. Accordingly, the chart below is to draw the frequency of nominalization frequencies on Rohingya issues in both of $B B C$ News and The Jakarta Post.

Chart 1. Divergence of Nominalization use in both of BBC News and The Jakarta Post

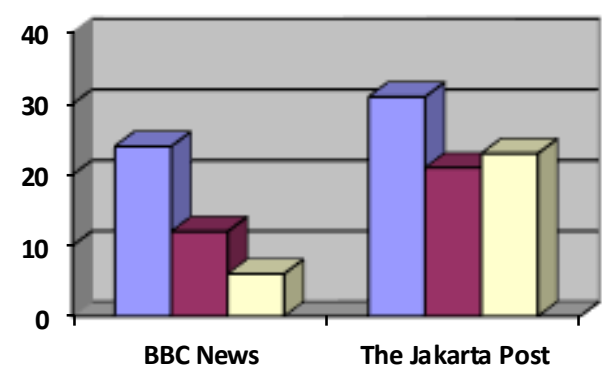

$$
\begin{aligned}
& \square \text { NOM as Adverbial } \\
& \square \text { NOM as Subject } \\
& \square \text { NOM as Object }
\end{aligned}
$$

From the chart above, the researcher summarizes that the articles served in the Indonesian's newspaper of the Jakarta Post are more occurrence to use nominalization either as adverbial, subject position, or object one than in

348 | Jurnal Kredo Vol. 2 No. 2 April 2019
America's newspaper of $B B C$ News, which is represented more explicit. It is strongly influenced by many factors because the Jakarta Post is coming from Indonesia's culture. Therefore, there are a lot of hidden actors serving through 
nominalization either in adverbial, subject position, or object position as stated by Van Leeuwen (2008). From the analysis above, both of media relatively illustrated their ideology, thought, and intention through constructing the text in the newspaper. They have similarities of essential purposes in creating a new public perspective and character in arguing the issue happened around of human life as stated by Susinskeine (2010). It is proved by numerous contexts involved in the newspapers such as political issues.

\section{CONCLUSION}

By investigating the authentic data taken from the article of newspapers to reveal the hidden meaning, the researcher can find out it through nominalizations. It really makes sense for the researcher to know the issue meaning toward the articles. It is more realible and representive to reduce and avoid the subjectivity in the analysis way. In the corpus tools, people can study the collocation and AntConc to demonstrate the meaning and pattern in different contexts. However, the corpus can be a central of data in providing the anaysis does not mean that the other sources is totally omitted (Lauder: 2010). This view can be strengthened by semantic theory of lexical and grammatical meaning (Saeed: 2016) which provided nominalization such as added by affixations namely everthing about prefix, suffix, confix, and circumfixes. Those affixations related by several theories which can be moldinged by critical discourse analysis/ CDA or systemic functional linguistics/ SFL.

Regarding to the issue analyzed through corpus tools, both of newspapers, the Jakarta Post and $B B C$ News, are indicating to raise the Rohingya issues. They totally concern toward solidarity and humanity issue in the world. They also tend to show their unity, democracy, and human right issues through their articles. Otherwise, they tend strongly to reject the radicalism of human victim in their news. Evidentially, it can be seen from the corpus data collected by many Rohingya articles of the Jakarta Post and BBC News in a week. From the finding afoirmentioned, the divergent of both newspapers is about nominalization appeared in the texts that signals about solidarity of both editorial newspapers. Even though both of newspapers are raising the solidarity issues but they can be diverged by the levels of its focus. Unfortunately, from the finding above, the Jakarta Post frequently tends to hide more the actor or subject of the action than $B B C$ News one. It means that $B B C$ news is more focusing on revealing the actor or subject clearly in the text. Otherwise, the Jakarta Post only implicates the action more. In other words, people should reveal the actor implicitly by themselves 


\section{REFERENCES}

Aronoff, Mark \& Kirsten Fudeman. 2005. What is Morphology. USA: Blackwell Publishing.

Atai, M.R. \& Hossein, R.A. 2009. On the representation of Iran's post-resolution nuclear issue in American news editorials: A Critical discourse analysis. The Iranian EFL Journal. Vol. 5. No. 20.

Baker, P. 2010. Sociolinguistics and Corpus Linguistics. Edinburgh: Edinburgh University Press.

Charles, Maggie, et. al. 2009. Academic Writing: At the Interface of Corpus and Discourse. New York: Continuum International Publishing Group.

Hou, Yu. 2014. A Corpus-Based Study of Nominalization in Translations of Chinese Literary Prose. Bern: Peter Lang.

Lauder, A. F. 2010. Data For Lexicography: The Central of Role of Corpus. Wacana. Vol 12. No. 2 p. 219-242.

Leeuwen, V. T. 2008. Discourse and Practice: New Tools for Critical Discourse Analysis. New York: Oxford University Press.

Malhberg, et.al. 2013. Phrase in Literary Contexts; Patterns and Distributions in Dickens's Novel. International Journal of Corpus Linguistics. Vol 18. No. 1. P.35-56.

Saeed, John I. 2016. Semantics: Fourth Edition. USA: Blackwell Publishing.

Susinskeine, Solveiga. 2010. Nominalization as Cohesion Device in British Newspaper Editorials. Filologija. Vol. 15. 1392-561.

Syamsuddin. \& Vismaia, S.D. 2011. Metode Penelitian Pendidikan Bahasa. Bandung: PT. Remaja Rosdakarya. 